Prepared in cooperation with the Indiana Office of Community and Rural Affairs

\title{
Flood-Inundation Maps for the Wabash River at Memorial Bridge at Vincennes, Indiana
}
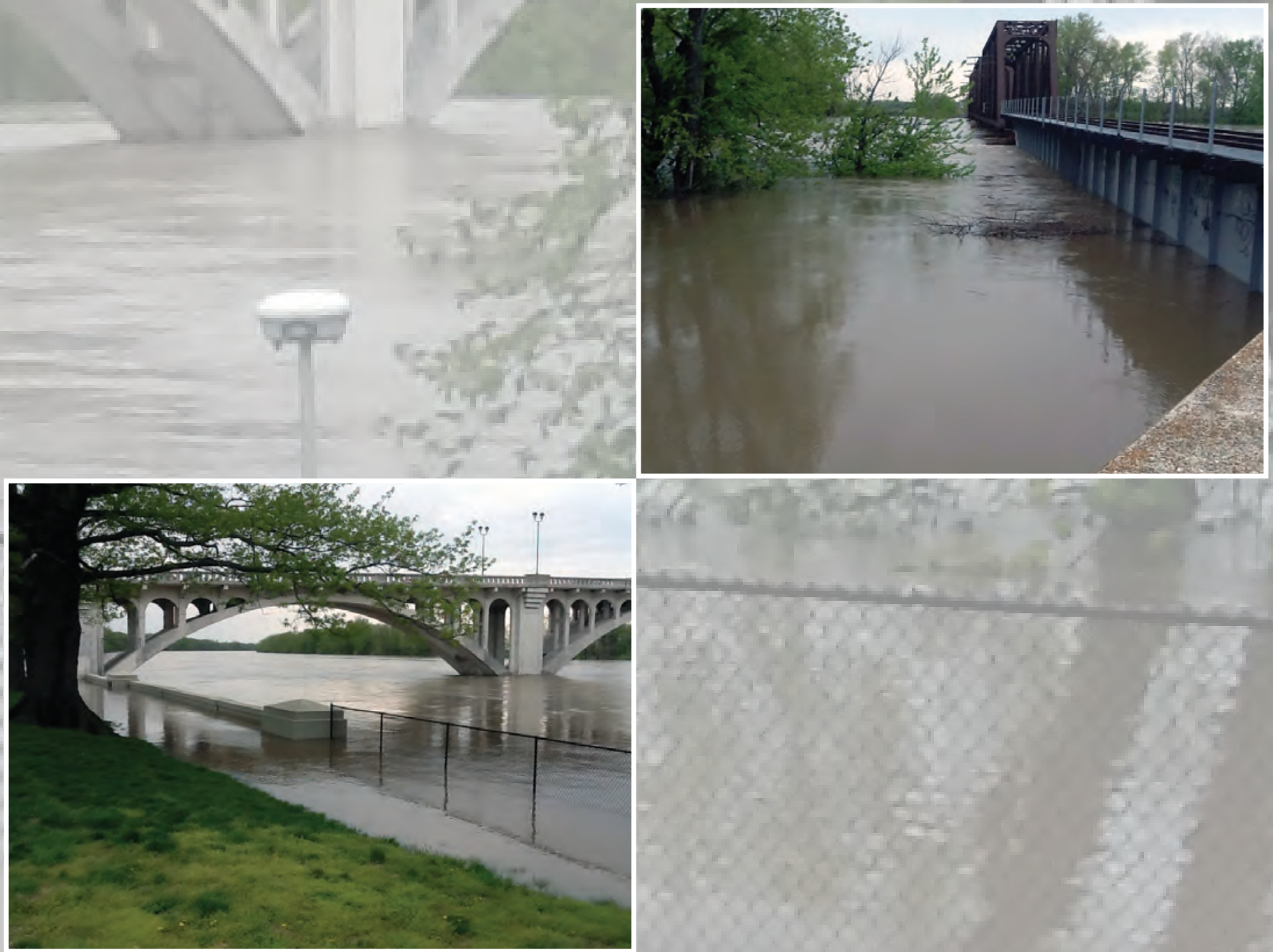

Scientific Investigations Report 2017-5073

U.S. Department of the Interior U.S. Geological Survey 
Cover photograph. Memorial Bridge in Vincennes, Indiana, April 26, 2013 (bottom left, photograph by Chad Menke, U.S. Geological Survey). Railroad bridge in Vincennes, Indiana, April 26, 2013 (top right, photograph by Chad Menke, U.S. Geological Survey). 


\section{Flood-Inundation Maps for the Wabash River at Memorial Bridge at Vincennes, Indiana}

By Kathleen K. Fowler and Chad D. Menke

Prepared in cooperation with the Indiana Office of Community and Rural Affairs

Scientific Investigations Report 2017-5073 


\title{
U.S. Department of the Interior \\ RYAN K. ZINKE, Secretary
}

\section{U.S. Geological Survey William H. Werkheiser, Acting Director}

\author{
U.S. Geological Survey, Reston, Virginia: 2017
}

For more information on the USGS - the Federal source for science about the Earth, its natural and living resources, natural hazards, and the environment-visit https://www.usgs.gov or call 1-888-ASK-USGS.

For an overview of USGS information products, including maps, imagery, and publications, visit https://store.usgs.gov/.

Any use of trade, firm, or product names is for descriptive purposes only and does not imply endorsement by the U.S. Government.

Although this information product, for the most part, is in the public domain, it also may contain copyrighted materials as noted in the text. Permission to reproduce copyrighted items must be secured from the copyright owner.

Suggested citation:

Fowler, K.K., and Menke, C.D., 2017, Flood-inundation maps for the Wabash River at Memorial Bridge at Vincennes, Indiana: U.S. Geological Survey Scientific Investigations Report 2017-5073, 10 p., https://doi.org/10.3133/ sir20175073.

ISSN 2328-0328 (online) 


\section{Contents}

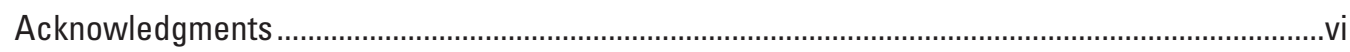

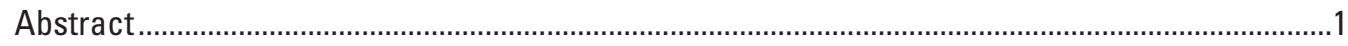

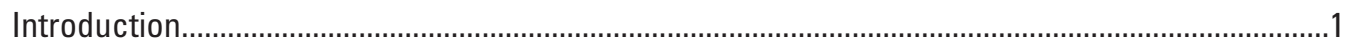

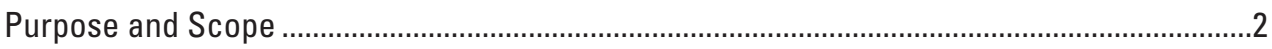

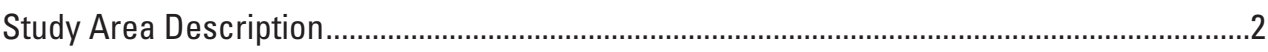

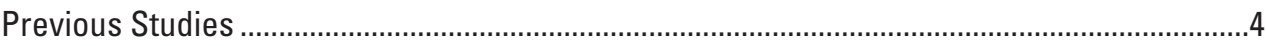

Creation of Flood-Inundation Map Library ...............................................................................

Computation of Water-Surface Profiles..................................................................................... 4

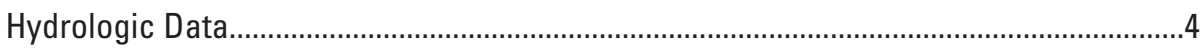

Topographic and Bathymetric Data ............................................................................... 5

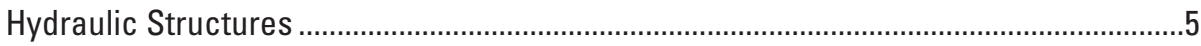

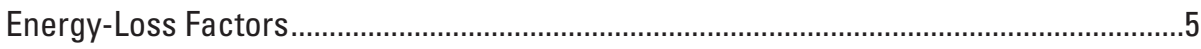

Hydraulic Model............................................................................................................6

Development of Water-Surface Profiles..............................................................................6

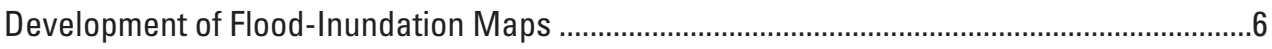

Flood-Inundation Map Delivery ....................................................................................

Disclaimer for Flood-Inundation Maps .............................................................................

Uncertainties and Limitations Regarding Use of Flood-Inundation Maps .......................7

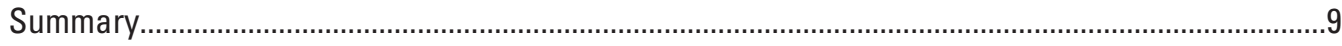

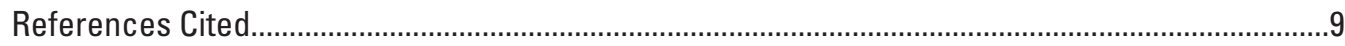




\section{Figures}

1. Map showing location of study reach for the Wabash River at Vincennes, Indiana, U.S. Geological Survey streamgage 03343010, and National Weather Service forecast site.

2. Map showing flood-inundation map for the Wabash River at Memorial Bridge at Vincennes, Indiana, corresponding to a stage of 28.00 feet at U.S. Geological Survey streamgage 03343010

\section{Tables}

1. U.S. Geological Survey streamgage information for the Wabash River at Memorial Bridge at Vincennes, Indiana .2

2. Coordinated discharges for selected annual exceedance probabilities for the Wabash River at Memorial Bridge at Vincennes, Indiana

3. Estimated discharges for corresponding stages and water-surface elevations at U.S. Geological Survey streamgage 03343010 used in the hydraulic model of the Wabash River at Memorial Bridge at Vincennes, Indiana.

4. Calibration of hydraulic model to target water-surface elevations at the U.S. Geological Survey streamgage on the Wabash River at Memorial Bridge at Vincennes, Indiana

5. Calibration of hydraulic model to water-surface elevations at selected locations along the Wabash River, Vincennes, Indiana, for the flood of April 27-28, 2013 


\section{Conversion Factors}

U.S. customary units to International System of Units

\begin{tabular}{|c|c|c|}
\hline Multiply & By & To obtain \\
\hline \multicolumn{3}{|c|}{ Length } \\
\hline foot $(\mathrm{ft})$ & 0.3048 & meter $(\mathrm{m})$ \\
\hline mile (mi) & 1.609 & kilometer (km) \\
\hline \multicolumn{3}{|c|}{ Area } \\
\hline square mile $\left(\mathrm{mi}^{2}\right)$ & 2.590 & square kilometer $\left(\mathrm{km}^{2}\right)$ \\
\hline \multicolumn{3}{|c|}{ Flow rate } \\
\hline cubic foot per second $\left(\mathrm{ft}^{3} / \mathrm{s}\right)$ & 0.02832 & cubic meter per second $\left(\mathrm{m}^{3} / \mathrm{s}\right)$ \\
\hline \multicolumn{3}{|c|}{ Hydraulic gradient } \\
\hline foot per mile (ft/mi) & 0.1894 & meter per kilometer $(\mathrm{m} / \mathrm{km})$ \\
\hline
\end{tabular}

\section{Datum}

Vertical coordinate information is referenced to either (1) stage, the height above an arbitrary datum established at a streamgage, or (2) elevation, the height above North American Vertical Datum of 1988 (NAVD 88).

Horizontal coordinate information is referenced to the North American Datum of 1983 (NAD 83). 


\section{Acknowledgments}

The authors wish to thank the city of Vincennes, Indiana, and the U.S. Army Corps of Engineers, Louisville District, for cooperating in funding the operation and maintenance of the gage used for this study. Special thanks are given to the Indiana Office of Community and Rural Affairs for their cooperation in this study and to the National Weather Service for their continued support to the U.S. Geological Survey flood-inundation mapping initiative. 


\title{
Flood-Inundation Maps for the Wabash River at Memorial Bridge at Vincennes, Indiana
}

\author{
By Kathleen K. Fowler and Chad D.Menke
}

\section{Abstract}

Digital flood-inundation maps for a 10.2-mile reach of the Wabash River from Sevenmile Island to 3.7 mile downstream of Memorial Bridge (officially known as Lincoln Memorial Bridge) at Vincennes, Indiana, were created by the U.S. Geological Survey (USGS) in cooperation with the Indiana Office of Community and Rural Affairs. The inundation maps, which can be accessed through the USGS Flood Inundation Mapping Science Web site at http://water. usgs.gov/osw/flood_inundation/ depict estimates of the areal extent and depth of flooding corresponding to selected water levels (stages) at USGS streamgage 03343010, Wabash River at Memorial Bridge at Vincennes, Ind. Near-real-time stages at this streamgage may be obtained on the Internet from the USGS National Water Information System at http:// waterdata.usgs.gov/ or the National Weather Service (NWS) Advanced Hydrologic Prediction Service at http:/water. weather.gov/ahps/, which also forecasts flood hydrographs at this site.

For this study, flood profiles were computed for the Wabash River reach by means of a one-dimensional stepbackwater model. The hydraulic model was calibrated by using the most current stage-discharge relations at USGS streamgage 03343010, Wabash River at Memorial Bridge at Vincennes, Ind., and preliminary high-water marks from a high-water event on April 27, 2013. The calibrated hydraulic model was then used to determine 19 water-surface profiles for flood stages at 1 -foot intervals referenced to the streamgage datum and ranging from 10 feet (ft) or near bankfull to $28 \mathrm{ft}$, the highest stage of the current stage-discharge rating curve. The simulated water-surface profiles were then combined with a Geographic Information System (GIS) digital elevation model (DEM, derived from Light Detection and Ranging [lidar] data having a 0.98 -ft vertical accuracy and 4.9-ft horizontal resolution) in order to delineate the area flooded at each water level.

The availability of these maps - along with Internet information regarding current stage from the USGS streamgage 03343010, and forecast stream stages from the NWS AHPSprovides emergency management personnel and residents with information that is critical for flood response activities such as evacuations and road closures, as well as for post-flood recovery efforts.

\section{Introduction}

The city of Vincennes, Indiana is an urban community with a reported population of 18,423 (U.S. Census Bureau, 2010). This community is located at the western edge of Knox County to the east of the Wabash River. The Wabash River flows along the border between Indiana and Illinois. Residents along Wabash River in and around Vincennes have experienced flooding numerous times, most recently in 2005, 2008, 2011, and 2013. Flood damage has been minimal due to the levee system on both sides of the river. Flood plains along the west side of river are less developed and composed mostly of agricultural areas. The east side of the river is heavily populated with urban development within the city boundaries. Upstream and downstream of Vincennes is a mix of agricultural and forested areas.

Prior to this study, officials from Vincennes, Ind., and Knox County relied on several information sources to make decisions on how to best alert the public and mitigate flood damages. One source of information is the Federal Emergency Management Agency (FEMA) Flood Insurance Study (FIS) for the city of Vincennes, Knox County (FEMA, 1984). A second source is the U.S. Geological Survey (USGS) streamgage, Wabash River at Memorial Bridge (known officially as Lincoln Memorial Bridge) at Vincennes, Ind. (03343010), from which current (U.S. Geological Survey, 2016c) and historical (U.S. Geological Survey, 2016e) water levels (stage) and discharges can be obtained. A third source is the National Weather Service (NWS) Advanced Hydrologic Prediction Service (AHPS) Web site for the streamgage, which issues forecasts of stage at the USGS streamgage (National Weather Service, 2016a).

Although the USGS streamgage and the NWS AHPS flood forecast information is particularly useful for residents in the immediate vicinity of a streamgage, it is generally of limited use to residents farther upstream or downstream because the water-surface elevation is not constant along the entire stream channel. Knowledge of a water level at a streamgage is 
difficult to translate into depth and areal extent of flooding at points distant from the streamgage. One way to address these informational gaps is to produce a library of flood-inundation maps that are referenced to the stages recorded at the USGS streamgage. By referring to the appropriate map, emergency responders can discern the severity of flooding (depth of water and areal extent), identify roads that are or will soon be flooded, and make plans for notification or evacuation of residents in harm's way for some distance upstream and downstream from the streamgage. In addition, the capability to visualize the potential extent of flooding has been shown to motivate residents to take precautions and heed warnings that they previously might have disregarded. In 2015-16, the USGS, in cooperation with the Indiana Office of Community and Rural Affairs, conducted a project to produce a library of flood-inundation maps for the Wabash River at Memorial Bridge at Vincennes, Ind.

\section{Purpose and Scope}

This report describes the development of a series of estimated flood-inundation maps for the Wabash River at Vincennes and identifies where on the Internet the maps can be accessed and ancillary data (Geographic Information System [GIS] flood polygons and depth grids) can be downloaded. Internet users can select estimated inundation maps that correspond to (1) flood stages at streamgage 03343010 and (2) the NWS forecasted stages at the NWS site VCNI3. The scope of the study was limited to the Wabash River reach extending from Sevenmile Island which is 6.7 miles (mi) upstream of USGS streamgage 03343010 at Memorial Bridge to about 3.7 mi downstream of the streamgage (fig. 1).

The flood-inundation maps were produced for flood levels referenced to the stage recorded at streamgage 03343010 (table 1); the streamgage is on the downstream side of the Memorial Bridge. The maps cover a range in stage from 10 to 28 feet (ft). The $10-\mathrm{ft}$ stage is approximately bankfull and is defined by the National Weather Service (2016a) as the "action stage" or that stage which, when reached by a rising stream, requires the NWS or a partner to take some type of mitigation action in preparation for possible significant hydrologic activity. The major flood stage, as determined by the NWS, is $28 \mathrm{ft}$. At this stage "a major flood is in progress. Water is at a critical stage for [the] levee beginning just south of Vincennes. If [the] levees fail, thousands of acres in rural Knox County flood" (National Weather Service, 2016b). A stage of 28.3-ft is the highest stage on the USGS stage-discharge rating curve number 4.0. During a recent flood at Vincennes on April 27, 2013, the stage was $27.72 \mathrm{ft}$, the third highest recorded stage at this site (U.S. Geological Survey, 2016d).

\section{Study Area Description}

The Wabash River near the city of Vincennes is in southwest Indiana in the Wabash Lowland physiographic section of the Southern Hills and Lowlands Region (Gray, 2000). The drainage area of the Wabash River is about 13,676 square miles $\left(\mathrm{mi}^{2}\right)$ at the upstream end of the modeled reach which is just below the mouth of Smalls Creek; 13,732 $\mathrm{mi}^{2}$ at USGS streamgage 03343010, Wabash River at Memorial Bridge at Vincennes, Ind.; and about 13,739 $\mathrm{mi}^{2}$ at the downstream extent (U.S. Geological Survey, 2016b) just upstream of the mouth of the Embarras River at Lawrence County, Illinois. The headwaters originate in northwest Ohio, and the river flows generally in a southwesterly direction. There are no significant tributaries to the Wabash River as it flows through the modeled reach. The study reach for the modeling is approximately $10.2 \mathrm{mi}$ long and has an average top-of-bank channel width of about $630 \mathrm{ft}$ and an average channel slope of about 0.41 feet per mile (ft/mi). Most of the land contiguous to the study reach is either urban (with industrial and residential development) or agricultural. Within the modeled reach, two major road crossings (US Highway 50 and State Road 441 [Memorial Bridge]) and one railroad crossing lie within the main channel or the adjacent flood plain. An earthen levee (Russel-Allison Levee) runs along the western bank of the study area in Illinois. Another earthen levee (Vincennes Levee) runs along the eastern bank from the northern city limits southward to the Memorial Bridge. A third levee (Brevoort Levee) extends along the southwestern part of the city.

Table 1. U.S. Geological Survey streamgage information for the Wabash River at Memorial Bridge at Vincennes, Indiana (station number 03343010).

[mi², square miles; ; degree; ', minutes; ", seconds; NAD 83, North American Datum of 1983; NAVD 88, North American Vertical Datum of 1988; ft, feet; ft³/s, cubic feet per second]

\begin{tabular}{|c|c|c|c|c|c|c|c|c|}
\hline Streamgage name & $\begin{array}{c}\text { Streamgage } \\
\text { number }\end{array}$ & $\begin{array}{c}\text { Drainage } \\
\text { area } \\
\left(\mathrm{mi}^{2}\right)\end{array}$ & $\begin{array}{l}\text { Latitude } \\
\text { (NAD 83) }\end{array}$ & $\begin{array}{l}\text { Longitude } \\
\text { (NAD 83) }\end{array}$ & $\begin{array}{l}\text { Period of } \\
\text { record }\end{array}$ & $\begin{array}{c}\text { Datum of } \\
\text { streamgage } \\
\text { (NAVD 88) }\end{array}$ & $\begin{array}{l}\text { Maximum recorded } \\
\text { flood elevation } \\
\text { (NAVD 88) and date }\end{array}$ & $\begin{array}{c}\text { Maximum } \\
\text { discharge during } \\
\text { period of record, } \\
\text { in } \mathrm{ft}^{3} / \mathrm{s} \text {, and date }\end{array}$ \\
\hline
\end{tabular}




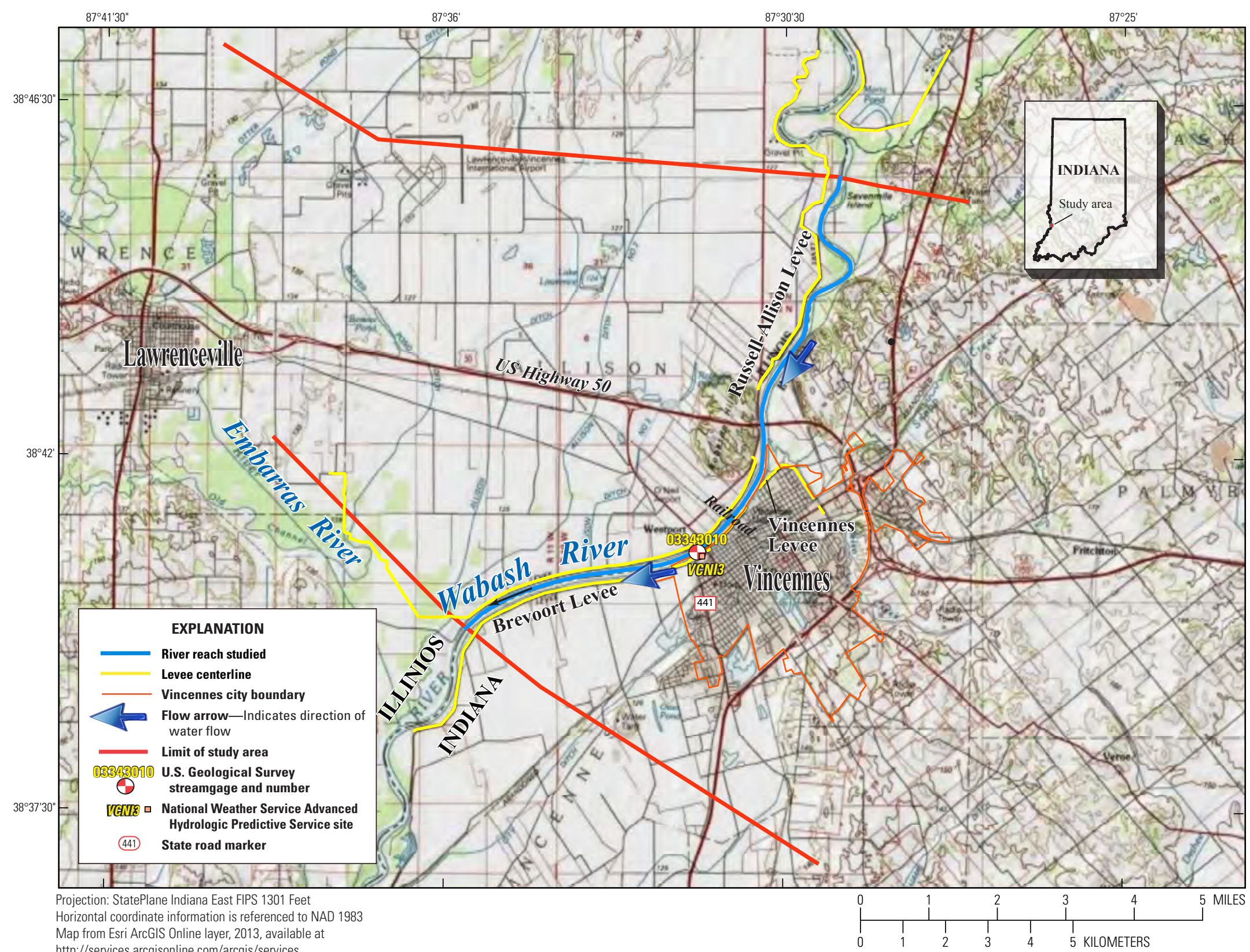

Map from Esri ArcGIS Online layer, 2013, available

http://services.arcgisonline.com/arcgis/services is used herein under license

Copyright (c) 2014 Esri and its licensors. All rights reserved.

Figure 1. Location of study reach for the Wabash River at Vincennes, Indiana, U.S. Geological Survey streamgage 03343010, and National Weather Service forecast site. 
Flood-Inundation Maps for the Wabash River at Memorial Bridge at Vincennes, Indiana

\section{Previous Studies}

The most recent FIS for the city of Vincennes, Knox County was published in 1984 (FEMA, 1984) and covers the incorporated areas. This 1984 study describes the levees around the city and the U.S. Army Corps of Engineers (USACE) certification of the Vincennes Levee. FEMA has also produced the National Flood Hazard Layer (NFHL), a digital database that contains flood hazard mapping data from FEMA's National Flood Insurance Program (NFIP). These layers include the study area in Knox County (FEMA, 2017). These maps outline the special flood hazard areas around Vincennes.

In addition, the Indiana Department of Natural Resources, the USGS, the Natural Resources Conservation Service, and the USACE have agreed to the discharge-frequency values for sites along many rivers in Indiana. The values are termed coordinated discharges and assure consistency among the State and Federal agencies that undertake streamflow studies (Indiana Department of Natural Resources, 2015). The coordinated discharges for the Wabash River at Vincennes were obtained from the USGS StreamStats Program for Indiana streams (U.S. Geological Survey, 2016b) and are listed in table 2.

Table 2. Coordinated discharges for selected annual exceedance probabilities for the Wabash River at Memorial Bridge at Vincennes, Indiana.

[mi² , square miles; $\mathrm{ft}^{3} / \mathrm{s}$, cubic feet per second; USGS, U.S. Geological Survey]

\begin{tabular}{lcccc}
\hline $\begin{array}{c}\text { Location on } \\
\text { Wabash River }\end{array}$ & $\begin{array}{c}\text { Drainage } \\
\text { area }\left(\mathbf{m i}^{2}\right)\end{array}$ & \multicolumn{2}{c}{$\begin{array}{c}\text { Coordinated discharges } \\
\text { indicated annual exceedance } \\
\text { probabilities (in percent) }\end{array}$} \\
\cline { 3 - 5 } & & $\mathbf{1 0}$ & $\mathbf{2}$ & $\mathbf{1}$ \\
\hline At USGS & 13,732 & 87,500 & 108,400 & 116,400 \\
streamgage & & & & \\
number & & & & \\
03343010 & & & & \\
\hline
\end{tabular}

${ }^{1}$ Data from Indiana Department of Natural Resources coordinated discharges for the Wabash River (modified) Vincennes gage.

\section{Creation of Flood-Inundation Map Library}

The USGS has standardized the procedures for creating flood-inundation maps for flood-prone communities (U.S. Geological Survey, 2016a) so that the process followed and products produced are similar regardless of which USGS office is responsible for the work. Tasks specific to construction of the maps were (1) compilation of flow data from streamgage 03343010; (2) collection of topographic and bathymetric data for selected cross sections and geometric data for Memorial Bridge, the railroad bridge, and the U.S. Highway 50 bridge; (3) estimation of energy-loss factors (roughness coefficients) in the stream channel and flood plain; (4) computation of water-surface profiles by use of the USACE's HEC-RAS computer program (USACE, 2010); (5) production of estimated flood-inundation maps at various stream stages by use of the USACE's HEC-GeoRAS computer program (USACE, 2011) and a GIS computer program called ArcGIS (Esri, 2014); and (6) preparation of the maps, both as shapefile polygons that depict the areal extent of flood inundation and as depth grids that provide the depth of floodwaters, for display on a USGS flood-inundation mapping application.

\section{Computation of Water-Surface Profiles}

The water-surface profiles used to produce the 19 floodinundation maps in this study were simulated by using HEC-RAS, version 4.1.0 (USACE, 2010). HEC-RAS is a one-dimensional step-backwater model for simulation of water-surface profiles with gradually varied, steady-state or unsteady-state flow computation options. The HEC-RAS analysis for this study was completed with the steady-state (gradually varied) flow computation option.

\section{Hydrologic Data}

The study area hydrologic network consists of one streamgage 03343010 (fig. 1), which has been in operation since 2009 and is colocated with the NWS AHPS site VCNI3. Prior to the installation of this streamgage, another streamgage was in operation $2.07 \mathrm{mi}$ upstream. This streamgage, Wabash River at Vincennes (03343000), was in operation from 1929 to 1994. Peak flow for this site was recorded in 1943 at an elevation of $421.76 \mathrm{ft}$ National Geodic Vertical Datum of 1929 and discharge of 189,000 cubic feet per second. Stage at the current streamgage is measured every 15 minutes, transmitted hourly by a satellite radio in the streamgage, and made available on the Internet through the USGS National Water Information System (NWIS; U.S. Geological Survey, 2016e). Stage data from this streamgage are referenced to a local datum but can be converted to water-surface elevations referenced to the North American Vertical Datum of 1988 (NAVD 88) by adding $393.97 \mathrm{ft}$. Continuous records of streamflow are computed from a stage-discharge relation, which has been developed for the streamgage, and are available through the USGS NWIS Web site. Preliminary high-water marks were collected and documented by USGS personnel during the flood that occurred on April 27, 2013 and also were used for model calibration. The flood stage was $27.72 \mathrm{ft}$, the third highest recorded stage at this site (U.S. Geological Survey, 2016d).

Steady-flow data consisted of flow regime, boundary conditions (normal depth), and peak-discharge information. The steady-flow data for the model were obtained from field measurements of streamflow and the stage-discharge rating at USGS streamgage 03343010, Wabash River at Memorial Bridge at Vincennes, Ind (table 3). All computations were based on discharge values with known stages from actual streamflow measurements or stage-discharge relations. 
Table 3. Estimated discharges for corresponding stages and water-surface elevations at U.S. Geological Survey streamgage 03343010 used in the hydraulic model of the Wabash River at Memorial Bridge at Vincennes, Indiana.

[ft, feet; NAVD 88, North American Vertical Datum of 1988; $\mathrm{ft}^{3} / \mathrm{s}$, cubic feet per second; USGS, U.S. Geological Survey]

\begin{tabular}{|ccc|}
\hline $\begin{array}{c}\text { Stage of water- } \\
\text { surface profile } \\
\text { (ft) }\end{array}$ & $\begin{array}{c}\text { Water-surface } \\
\text { elevation } \\
\text { (ft, NAVD 88) }\end{array}$ & $\begin{array}{c}\text { Estimated discharge } \text { at }^{2} \\
\text { USGS streamgage number } \\
\text { 03343010 } \text { (ft }^{\mathbf{3}} \mathbf{s} \text { ) }\end{array}$ \\
\hline 10 & 403.07 & 17,900 \\
\hline 11 & 404.07 & 20,700 \\
\hline 12 & 405.07 & 23,600 \\
\hline 13 & 406.07 & 26,600 \\
\hline 14 & 407.07 & 29,800 \\
\hline 15 & 408.07 & 33,000 \\
\hline 16 & 409.07 & 36,400 \\
\hline 17 & 410.07 & 39,900 \\
\hline 18 & 411.07 & 44,200 \\
\hline 19 & 412.07 & 48,700 \\
\hline 20 & 413.07 & 53,400 \\
\hline 21 & 414.07 & 58,400 \\
\hline 22 & 415.07 & 63,500 \\
\hline 23 & 416.07 & 68,800 \\
\hline 24 & 417.07 & 74,300 \\
\hline 25 & 418.07 & 80,000 \\
\hline 26 & 419.07 & 86,300 \\
\hline 27 & 420.07 & 92,900 \\
\hline 28 & 421.07 & 99,700 \\
\hline
\end{tabular}

${ }^{1}$ Water-surface profiles are 1-foot increments of stage, referenced to the gage datum of the U.S. Geological Survey streamgage, Wabash River at Memorial Bridge at Vincennes, Indiana (station 03343010).

${ }^{2}$ Discharge from U.S. Geological Survey rating number 4.0, effective May 6, 2013.

\section{Topographic and Bathymetric Data}

All topographic data used in this study are referenced vertically to NAVD 88 and horizontally to the North American Datum of 1983. Cross-section elevation data were obtained from a digital elevation model (DEM) that was derived from light detection and ranging (lidar) data that were collected as part of a statewide project during 2011-13 by Woolpert, Inc. (2011). The lidar data for Knox County were collected in 2013. The DEM was obtained from the Indiana Spatial Data Portal (Indiana University, 2015). The original lidar data have horizontal resolution of $4.9 \mathrm{ft}$ and vertical accuracy of $0.98 \mathrm{ft}$ at a 95-percent confidence level based on a root mean squared error of $0.49 \mathrm{ft}$ for the "open terrain" land-cover category. By these criteria, the lidar data support production of 2-ft contours (Dewberry, 2012); the final DEM, which was resampled to a grid-cell size of 10 -ft by $10-\mathrm{ft}$ to decrease the GIS processing time, has a vertical accuracy of plus or minus $1 \mathrm{ft}$. By using HEC-GeoRAS (a set of procedures, tools, and utilities for processing geospatial data in ArcGIS), elevation data were extracted from the DEM for 149 cross sections. These data subsequently were input to the HEC-RAS model.
Because lidar data cannot provide ground elevations below a stream's water surface, channel cross sections were surveyed by USGS field crews during December 2013. Crosssectional depths were measured by using hydroacoustic instrumentation at 35 locations. A differential global positioning system with real-time kinematic technology was used to derive horizontal locations and the elevation of the water surface at each surveyed cross section.

\section{Hydraulic Structures}

Three structures, consisting of two road crossings (State Road 441 [Memorial Bridge] and State Highway 50) and a railroad bridge, have the potential to affect water-surface elevations during floods along the river. Bridge-geometry data were obtained from field surveys conducted by personnel from the USGS Indiana-Kentucky Water Science Center. There are also levee sections along the banks of the river. These levees constrict flow during periods of high water. The Russell-Allison Levee is the longest section and borders the river along the west and north sides. The Brevoort Levee is at the downstream third of the study reach on the south bank of the river. The Vincennes Levee is within the city limits and was designed to provide protection to the northern areas of the city. This levee has USACE certification that the community has protection from the 100year frequency flood. This certification is conditional to operating an emergency closure at Memorial Bridge in an appropriate and timely manner (FEMA, 1984). The area protected by the levee features can be obtained from the USACE National Levee Database (USACE, 2017).

\section{Energy-Loss Factors}

Hydraulic analyses require the estimation of energy losses that result from frictional resistance exerted by a channel on flow. These energy losses are quantified by the Manning's roughness coefficient (" $n$ " value) (Arcement and Schneider, 1989). Initial (pre-calibration) $n$ values were selected on the basis of field observations and high-resolution aerial photographs. An $n$ value of 0.03 was selected for the main channel because it is fairly clean with a low gradient. An $n$ value of 0.08 was used for the overbank areas, which are dominated by agricultural fields and forest in the rural sections of the study reach, and the residential and commercial areas of Vincennes both east and west of the river.

The initial $n$ values were adjusted as part of the calibration process, which involved minimizing the differences between simulated and observed water-surface elevations at the streamgage and elsewhere along the study reach. Roughness-coefficient adjustment factors were varied by flow and adjusted until the simulated water-surface elevations approximated the target water-surface elevations. The actual $n$ values were computed by multiplying the initial $n$ value by each of the roughness-coefficient adjustment factors. Main channel $n$ values ranged from 0.029 to 0.0408 , and overbank values ranged from 0.076 to 0.108 . 


\section{Hydraulic Model}

The HEC-RAS analysis for this study was done by using the steady-state flow computation option. Steady-state flow data consisted of flow regime, boundary conditions, and peak flows that produced water-surface elevations at the streamgage cross section that matched target water-surface elevations. These target elevations coincided with even $1 \mathrm{ft}$ increments of stage, referenced to the local gage datum. Subcritical (tranquil) flow regime was assumed for the simulations. Normal depth, based on an estimated average channel slope of 0.0001 from data obtained from Indiana DNR historic profiles and the channel slope at the downstream end of the study reach, was used as the downstream boundary condition of the reach. The peak flows that were used in the model are discussed in the "Hydrologic Data" section.

The hydraulic model was calibrated to the stage-discharge relation (USGS rating no. 4.0, June 19, 2014) at USGS streamgage 03343010, Wabash River at Memorial Bridge at Vincennes, Ind., and preliminary high-water marks from the flood of April 27, 2013. Model calibration was accomplished by adjusting Manning's $n$ values and, in some cases, changing the channel cross section or slope until the results of the hydraulic computations closely agreed with the known flood discharge and stage values. Differences between target and simulated water levels for measured or rated flows at USGS streamgage 03343010 were less than or equal to about $0.37 \mathrm{ft}$ (table 4). Differences between target and simulated water levels for models calibrated to preliminary high-water marks in the study reach from the flood of April 2013 were less than or equal to about $0.65 \mathrm{ft}$ (table 5). The results demonstrate that the model is capable of simulating reasonable water levels over a wide range of flows in the basin..

\section{Development of Water-Surface Profiles}

The calibrated hydraulic model was used to generate water-surface profiles for a total of 19 stages at 1-ft intervals between $10 \mathrm{ft}$ and $28 \mathrm{ft}$ as referenced to the local datum of the Wabash River at Memorial Bridge streamgage. These stages correspond to elevations of $403.97 \mathrm{ft}$ to $421.97 \mathrm{ft}$, NAVD 88, respectively.

\section{Development of Flood-Inundation Maps}

Flood-inundation maps were created in a GIS for the 19 water-surface profiles by combining the profiles and digital elevation model data. The DEM data were derived from the same lidar data described previously in the "Topographic and Bathymetric Data" section and therefore have an estimated vertical accuracy of $2 \mathrm{ft}$ (that is, plus or minus $1 \mathrm{ft}$ ). Estimated flood-inundation boundaries for each simulated profile were developed with HEC-GeoRAS software (U.S. Army Corps of Engineers, 2011), which allows the preparation of geometric data for import into HEC-RAS and processes simulation
Table 4. Calibration of hydraulic model to target water-surface elevations at the U.S. Geological Survey streamgage on the Wabash River at Memorial Bridge at Vincennes, Indiana (station number 03343010).

[ft, feet; NAVD 88, North American Vertical Datum of 1988]

\begin{tabular}{cccc}
\hline $\begin{array}{c}\text { Stage of } \\
\text { water- } \\
\text { surface } \\
\text { profile (ft) }\end{array}$ & $\begin{array}{c}\text { Target water- } \\
\text { surface } \\
\text { elevation } \\
\text { (ft, NAVD 88) }\end{array}$ & $\begin{array}{c}\text { Simulated } \\
\text { water-surface } \\
\text { elevation } \\
\text { (ft, NAVD 88) }\end{array}$ & $\begin{array}{c}\text { Elevation } \\
\text { difference } \\
\text { (ft) }\end{array}$ \\
\hline 10 & 403.97 & 403.60 & -0.37 \\
\hline 11 & 404.97 & 404.64 & -0.33 \\
\hline 12 & 405.97 & 405.68 & -0.29 \\
\hline 13 & 406.97 & 406.71 & -0.26 \\
\hline 14 & 407.97 & 407.74 & -0.23 \\
\hline 15 & 408.97 & 408.72 & -0.25 \\
\hline 16 & 409.97 & 409.70 & -0.27 \\
\hline 17 & 410.97 & 410.68 & -0.29 \\
\hline 18 & 411.97 & 411.81 & -0.16 \\
\hline 19 & 412.97 & 412.90 & -0.07 \\
\hline 20 & 413.97 & 413.97 & 0.00 \\
\hline 21 & 414.97 & 415.04 & 0.07 \\
\hline 22 & 415.97 & 416.06 & 0.09 \\
\hline 23 & 416.97 & 417.08 & 0.11 \\
\hline 24 & 417.97 & 418.09 & 0.12 \\
\hline 25 & 418.97 & 419.08 & 0.11 \\
\hline 26 & 419.97 & 420.14 & 0.17 \\
\hline 27 & 420.97 & 421.20 & 0.23 \\
\hline 28 & 421.97 & 422.30 & 0.33 \\
\hline & & & \\
\hline
\end{tabular}

results exported from HEC-RAS (USACE, 2010). Shapefile polygons and depth grids of the inundated areas for each profile were modified, as required, in the ArcMap application of ArcGIS to ensure a hydraulically reasonable transition of the flood boundaries between modeled cross sections. The datasets (depth grids and shapefiles) used in this study are available through a data release at https://doi.org/10.5066/F7ZG6QGC (Fowler, 2017).

Any inundated areas that were detached from the main channel were examined to identify subsurface connections with the main river, such as through culverts under roadways. Where such connections existed, the mapped inundated areas were retained in their respective flood maps; otherwise, the erroneously delineated parts of the flood extent were deleted. The flood-inundation areas are overlaid on high-resolution, geo-referenced, aerial photographs of the study area. Bridge surfaces are displayed as inundated regardless of the actual water-surface elevation in relation to the lowest structural chord of the bridge or the bridge deck.

Estimates of water depth can be obtained from the depthgrid data that are included with the presentation of the flood maps on an interactive USGS mapping application described in the following section, "Flood-Inundation Map Delivery." The flood map corresponding to the highest simulated watersurface profile $(28 \mathrm{ft}$ ) with and without the levees in place 
Table 5. Calibration of hydraulic model to water-surface elevations at selected locations along the Wabash River, Vincennes, Indiana, for the flood of April 27-28, 2013.

[ft, feet; NAVD 88, North American Vertical Datum of 1988; N, north]

\begin{tabular}{|c|c|c|c|c|}
\hline Location & $\begin{array}{l}\text { High water-surface } \\
\text { mark field } \\
\text { identification } \\
\text { number }^{1}\end{array}$ & $\begin{array}{l}\text { Surveyed high water- } \\
\text { surface mark elevation } \\
\text { (ft, NAVD 88) }\end{array}$ & $\begin{array}{l}\text { Modeled water- } \\
\text { surface elevation² } \\
\text { (ft, NAVD 88) }\end{array}$ & $\begin{array}{l}\text { Elevation } \\
\text { difference } \\
\text { (ft) }\end{array}$ \\
\hline Oliphant Dr. at Chipekokee Park & 2 & 423.22 & 423.36 & 0.14 \\
\hline Downstream of Railroad on east bank of river & 5 & 422.05 & 422.30 & 0.25 \\
\hline $\begin{array}{l}\text { Near east bank of river approximately } 220 \text { feet up- } \\
\text { stream of SR } 441\end{array}$ & 6 & 421.64 & 421.85 & 0.21 \\
\hline CR 1570 East near west bank of river & 7 & 420.60 & 420.72 & 0.13 \\
\hline CR 730 East near west bank of river & 8 & 419.73 & 419.75 & 0.02 \\
\hline
\end{tabular}

is presented in figure 2. This map provides a comparison to indicate areas of uncertainty if levees were to be breached or overtopped.

\section{Flood-Inundation Map Delivery}

The current study documentation is available online at the USGS Publications Warehouse (http://doi.org/sir/2017/ sir20175073). Also, a Flood Inundation Mapping Science Web site http://water.usgs.gov/osw/flood_inundation/ (U.S. Geological Survey, 2016a) has been established to make USGS flood-inundation study information available to the public; that site links to a mapping application that presents map libraries and provides detailed information on flood extents and depths for modeled sites. The mapping application enables the production of customized flood-inundation maps from the map library for the Wabash River at Vincennes, Ind. A link on this Web site connects to the USGS NWIS (U.S. Geological Survey, 2016c), which presents the current stage and streamflow at USGS streamgage 03343010 to which the floodinundation maps are referenced. A second link connects to the NWS AHPS site (National Weather Service, 2016) so that the user can obtain applicable information on forecasted peak stage. The estimated flood-inundation maps are displayed in sufficient detail so that preparations for flooding and decisions for emergency response can be performed efficiently. Depending on the flood magnitude, roadways are shown as shaded (inundated and likely impassable) or not shaded (dry and passable) to facilitate emergency planning and use. Bridges are shaded - that is, shown as inundated - regardless of the flood magnitude. At and above a stage of $18 \mathrm{ft}$, some overbank areas are shown with green shading. The green shading indicates areas of uncertainty due to the presence of levees.
These are areas generally protected by the levees but could become inundated were the levees to breach or overtop. At the 28-ft stage the Russel-Allison Levee may be overtopped in some areas. A shaded building should not be interpreted to indicate that the structure is completely submerged, rather that bare earth surfaces in the vicinity of the building are inundated. In these instances, the water depth (as indicated in the mapping application by holding the cursor over an inundated area) near the building would be an estimate of the water level inside the structure, unless flood-proofing measures had been implemented.

\section{Disclaimer for Flood-Inundation Maps}

The flood-inundation maps should not be used for navigation, regulatory, permitting, or other legal purposes. The USGS provides these maps "as-is" for a quick reference, emergency planning tool but assumes no legal liability or responsibility resulting from the use of this information.

\section{Uncertainties and Limitations Regarding Use of Flood-Inundation Maps}

Although the flood-inundation maps represent the boundaries of inundated areas with a distinct line, some uncertainty is associated with these maps. The flood boundaries shown were estimated on the basis of water stages and streamflows at selected USGS streamgages. Water-surface elevations along the stream reaches were estimated by steady-state hydraulic modeling, assuming unobstructed flow, and using streamflows and hydrologic conditions anticipated at the USGS streamgage. The hydraulic model reflects the landcover characteristics and any bridge, levee, or other hydraulic 


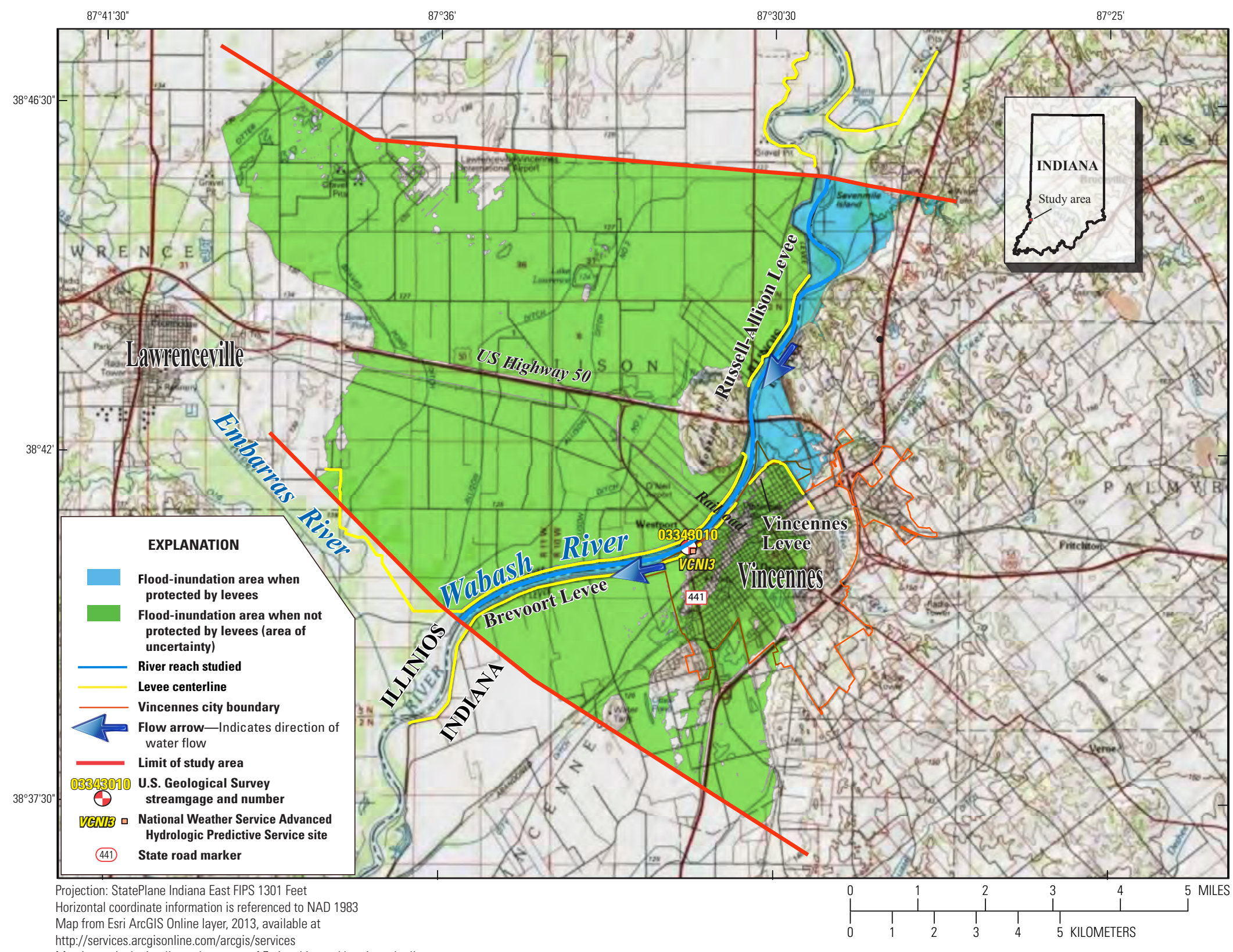

Map image is the intellectual property of Esri and is used herein under license.

Copyright $@ 2014$ Esri and its licensors. All rights reserved.

Figure 2. Flood-inundation map for the Wabash River at Memorial Bridge at Vincennes, Indiana, corresponding to a stage of 28.00 feet at U.S. Geological Survey streamgage 03343010 . 
structures existing as of December 2013. Unique meteorological factors (timing and distribution of precipitation) may cause actual streamflows along the modeled reach to vary from those assumed during a flood, which may lead to deviations in the water-surface elevations and inundation boundaries shown. Additional areas may be flooded due to unanticipated conditions such as changes in the streambed elevation or roughness, backwater into major tributaries along a main-stem river, or backwater from localized debris or ice jams. The accuracy of the floodwater extent portrayed on these maps will vary with the accuracy of the digital elevation model used to simulate the land surface.

If this series of flood-inundation maps will be used in conjunction with National Weather Service (NWS) river forecasts, the user should be aware of additional uncertainties that may be inherent or factored into NWS forecast procedures. The NWS uses forecast models to estimate the quantity and timing of water flowing through selected stream reaches in the United States. These forecast models (1) estimate the amount of runoff generated by precipitation and snowmelt, (2) simulate the movement of floodwater as it proceeds downstream, and (3) predict the flow and stage (and water-surface elevation) for the stream at a given location (AHPS forecast point) throughout the forecast period (every 6 hours and 3 to 5 days out in many locations). For more information on AHPS forecasts, please see: http://water.weather.gov/ahps/pcpn_and_ river_forecasting.pdf.

The study reach includes three levee sections which can produce variable flood extents and water depths on the landward side of the levee embankments. The extent and depth of flooding that could occur on the landward side of the levees if a breech occurred are uncertain. A stage of $16 \mathrm{ft}$ was selected to begin estimating flood-inundation extent if the levees were to become ineffective. Sixteen feet is the action stage at this streamgage according to the NWS designated flood stages. The extent and depth of flooding will vary with the elevation of the water surface in the river and the length of time that the water level remains above the elevation of low spots or breaches on the levee. As such, areas of the community protected by levees are subject to potential risk if the levees fail or are overtopped. The "areas of uncertainty due to a levee" are displayed in green to reflect this uncertainty. Additional uncertainties and limitations pertinent to this study may be described elsewhere in this report.

\section{Summary}

A series of 19 digital flood-inundation maps was developed in cooperation with Indiana Office of Rural and Community Affairs for the Wabash River at Memorial Bridge (known officially as Lincoln Memorial Bridge), Vincennes, Indiana. The maps cover a reach about 10.2 mile long from Sevenmile Island near the upstream extent to 3.7 miles downstream of Memorial Bridge at Vincennes, Ind. The maps were developed by using the United States Army Corps of Engineer's HECRAS and HEC-GeoRAS programs to compute water-surface profiles and to delineate estimated flood-inundation areas and depths of flooding for selected stream stages. The HEC-RAS hydraulic model was calibrated to the stage-discharge relation at the Wabash River streamgage at Vincennes (03343010) and the flood of April 2013. The model was used to compute 19 water-surface profiles for flood stages referenced to the streamgage datum and ranging from 10 feet, or near bankfull, to 28 feet, which is the highest stage of the stage-discharge rating. The simulated water-surface profiles were then combined with a Geographic Information System digital elevation model derived from light detection and ranging (lidar) data to delineate estimated flood-inundation areas as shapefile polygons and depth grids for each profile. These flood-inundation polygons were overlaid on a geo-referenced, digital raster graphic (topographic map) of the study area. The flood maps are available through a mapping application that can be accessed on the USGS Flood Inundation Mapping Science Web site (http:// water.usgs.gov/osw/flood_inundation/).

Interactive use of the maps on this mapping application can give users a general indication of depth of water at any point by using the mouse cursor to click within the shaded areas. These maps, in conjunction with the real-time stage data from the USGS streamgage, Wabash River at Memorial Bridge at Vincennes, Ind. (station number 03343010), and forecasted flood stage data from the National Weather Service Advanced Hydrologic Prediction Service will help to guide the general public in taking individual safety precautions and will provide emergency management personnel with a tool to efficiently manage emergency flood operations and postflood recovery efforts.

\section{References Cited}

Arcement, G.J., Jr., and Schneider, V.R., 1989, Guide for selecting Manning's roughness coefficients for natural channels and flood plains: U.S. Geological Survey Water-Supply Paper 2339, 38 p.

Dewberry, 2012, National enhanced elevation assessment: Fairfax, Va., Dewberry, 84 p., accessed July 2014 at http:// www.dewberry.com/services/geospatial/national-enhancedelevation-assessment.

Esri, 2014, ArcGIS: accessed July 2014, at http://www.esri. com/software/arcgis/.

Federal Emergency Management Agency, 1984, Flood insurance study for the City of Vincennes, Knox County, Indiana: Washington D.C., Flood Insurance Study Number 180120V000, 14 p. 
Federal Emergency Management Agency, 2017, FEMA Flood Map Service Center, accessed March 2017 at http://msc. fema.gov/portal/.

Fowler, K.K., 2017, Wabash River at Vincennes, Indiana, flood-inundation geospatial datasets: U.S. Geological Sur-vey data release, https://doi.org/10.5066/F7ZG6QGC.

Gray, H.H., 2000, Physiographic divisions of Indiana: Bloomington, Ind., Indiana Geological Survey Special Report 61, $15 \mathrm{p} ., 1 \mathrm{pl}$.

Indiana Department of Natural Resources, 2015, Coordinated discharges of selected streams in Indiana, accessed January 2015 at http://www.in.gov/dnr/water/4898.htm.

Indiana University, 2015, Indiana spatial data portal, accessed March 2015 at http://gis.iu.edu/.

National Weather Service, 2016a, Advanced hydrologic prediction service, Wabash River at Vincennes, Indiana (NHRI3), accessed May 2016 at http://water.weather.gov/ ahps $2 /$ hydrograph.php?wfo=pah\&gage=vcni3 .

National Weather Service, 2016b, National Weather Service glossary, accessed June 2016 at http://w1.weather.gov/glossary/index.php?word=action+stage.

U.S. Army Corps of Engineers, Hydrologic Engineering Center, 2011, HEC-GeoRAS, GIS tools for support of HECRAS using ArcGIS, user's manual, version 10.1 [variously paged.]

U.S. Army Corps of Engineers, Hydrologic Engineering Center, 2010, HEC-RAS river analysis system-Hydraulic reference manual, version 4.1 [variously paged.]

U.S. Army Corps of Engineers, 2017 National Levee Database: Accessed January 2017 at http://nld.usace.army.mil/ egis/f?p=471:1:0::NO.

U.S. Census Bureau, 2010, 2010 Census interactive population search IN-Vincennes town: Washington, D.C., accessed December 2016 at https://www.census.gov/quickfacts/table/ PST045216/1879208,18.

U.S. Geological Survey, 2016a, Flood Inundation Mapping (FIM) Program: U.S. Geological Survey Web site, accessed March 2016 at http://water.usgs.gov/osw/flood_inundation/.

U.S. Geological Survey, 2016b, StreamStats in Indiana: U.S. Geological Survey StreamStats Program, accessed April 2016 at https://water.usgs.gov/osw/streamstats/indiana.html.

U.S. Geological Survey, 2016c, USGS 03343010 Wabash River at Vincennes, IN — Current/historical observations: U.S. Geological Survey National Water Information System, accessed December 2014 at http://nwis.waterdata.usgs. gov/in/nwis/uv?site_no $=03343010$.
U.S. Geological Survey, 2016d, USGS 03343010 Wabash River at Vincennes, IN-Peak streamflow: U.S. Geological Survey National Water Information System, accessed December 2016 at http://nwis.waterdata.usgs.gov/in/nwis/ peak site_no $=03343010 \&$ agency_cd $=$ USGS\&format $=\mathrm{html}$.

U.S. Geological Survey, 2016e, USGS 03343010 Wabash River at Vincennes, IN - Summary of all available data: U.S. Geological Survey National Water Information System, accessed December 2014 at http://nwis.waterdata. usgs.gov/in/nwis/nwisman/?site_no=03343010\&agency_ $\mathrm{cd}=$ USGS.

Woolpert, Inc., 2011, Woolpert Order No. 71177, Indiana Statewide Imagery and Lidar Program, remote sensing image: Dayton, Ohio, Woolpert, Inc., metadata accessed January 21, 2015, at http://gis.iu.edu/files/documents/ in2011_ortho.txt.

Publishing support provided by:

Madison and Rolla Publishing Service Centers

For additional information concerning this publication, contact: Director, Indiana Water Science Center 5957 Lakeside Blvd. Indianapolis, IN 46278

(317) 290-3333

Or visit the Indiana Water Science Center website at: https://in.water.usgs.gov 

